\title{
Early decrease in dietary protein:energy ratio by fat addition and ontogenetic changes in muscle growth mechanisms of rainbow trout: short- and long-term effects
}

\author{
Hélène Alami-Durante*, Marianne Cluzeaud, Carine Duval, Patrick Maunas, Virginia Girod-David and \\ Françoise Médale
}

INRA, UR 1067 Nutrition Métabolisme Aquaculture, Aquapôle, F-64310 Saint-Pée-sur-Nivelle, France

(Submitted 27 November 2013 - Final revision received 17 April 2014 - Accepted 12 May 2014 - First published online 20 June 2014)

\begin{abstract}
As the understanding of the nutritional regulation of muscle growth mechanisms in fish is fragmentary, the present study aimed to (1) characterise ontogenetic changes in muscle growth-related genes in parallel to changes in muscle cellularity; (2) determine whether an early decrease in dietary protein:energy ratio by fat addition affects the muscle growth mechanisms of rainbow trout (Oncorhynchus mykiss) alevins; and (3) determine whether this early feeding of a high-fat (HF) diet to alevins had a long-term effect on muscle growth processes in juveniles fed a commercial diet. Developmental regulation of hyperplasia and hypertrophy was evidenced at the molecular (expression of myogenic regulatory factors, proliferating cell nuclear antigen and myosin heavy chains (MHC)) and cellular (number and diameter of white muscle fibres) levels. An early decrease in dietary protein:energy ratio by fat addition stimulated the body growth of alevins but led to a fatty phenotype, with accumulation of lipids in the anterior part, and less caudal muscle when compared at similar body weights, due to a decrease in both the white muscle hyperplasia and maximum hypertrophy of white muscle fibres. These HF diet-induced cellular changes were preceded by a very rapid down-regulation of the expression of fast-MHC. The present study also demonstrated that early dietary composition had a long-term effect on the subsequent muscle growth processes of juveniles fed a commercial diet for 3 months. When compared at similar body weights, initially HF diet-fed juveniles indeed had a lower mean diameter of white muscle fibres, a smaller number of large white muscle fibres, and lower expression levels of MyoD1 and myogenin. These findings demonstrated the strong effect of early feed composition on the muscle growth mechanisms of trout alevins and juveniles.
\end{abstract}

Key words: Nutrition: Myogenesis: Hyperplasia: Hypertrophy: Myogenic regulatory factor: Myosin: Cellularity

As in other animals and humans, increasing the supply of digestible energy promotes weight gain in fish. Fish use a large proportion of dietary proteins to cover their energy requirements. As protein sources are costly ingredients, research has been undertaken in order to increase the dietary input of non-protein digestible energy. Dietary carbohydrates are less efficiently utilised as an energy source by high trophiclevel fish species such as salmonids than by low trophic-level fish species. In contrast, dietary lipids are highly digestible and constitute a major source of energy in salmonid diets. For a given dietary protein level, an increase in fat level in the diets of rainbow trout generally enhances growth and protein utilisation $^{(1,2)}$. The improvement in protein utilisation is due to increasing contribution of non-protein energy sources to overall energy expenditure, which leads to a reduction in $\mathrm{N}$ excretion and improves the quality of effluent discharge from fish farms ${ }^{(3)}$. Information on the effects of changes in dietary protein:energy ratio on the growth processes of fish during early stages is lacking, despite the fact that there is increasing evidence from studies in human and various animal models, including fish, that the nutritional regulation of growth is life-cycle stage-specific, and that early stages are particularly sensitive to the deficiency or excess of some nutrients. Fish hatch immature, with a yolk sac, morphology, anatomy (e.g. unopened mouth) and physiology that are very different from those of the adult. The period of development and growth that follows the first exogenous feeding is typified by an increase in the activity of enzymes involved in digestive function and muscle glycolytic metabolism ${ }^{(4,5)}$, and a remodelling of the relative volume of the main tissues and organs that make up the body, with positive allometry of axial locomotor muscles ${ }^{(6)}$.

Abbreviations: cDNA, complementary DNA; df, days of feeding; HF, high fat; LF, low fat; mf, months of feeding; MHC, myosin heavy chain; MRF, myogenic regulatory factor; Myf5, myogenic factor 5; MyoD1, myogenic differentiation 1; Myog, myogenin; PCNA, proliferating cell nuclear antigen. 
In rainbow trout (Oncorbynchus mykiss), the growth of white skeletal muscle, which constitutes the bulk of the axial locomotor muscle, occurs after hatching by both the recruitment of new muscle fibres (hyperplasia) and the enlargement of the previously formed fibres (hypertrophy) ${ }^{(7,8)}$, as in other aquaculture fish reaching a large adult body size ${ }^{(9)}$. The relative contributions of hyperplasia and hypertrophy to the growth of white muscle in trout change when the length of the trout increases ${ }^{(7,8)}$, as indicated by length-related changes in white muscle cellularity (i.e. in the total number of white muscle fibres and their size distribution): hyperplasia contributes more to white muscle growth in small rather than large trout. In addition to this developmental regulation, the cellularity of fish white muscle has been established as being triggered by temperature from the embryonic to the adult period of life ${ }^{(10-13)}$ and affected by starvation and feed restriction in fingerlings, juveniles and mature fish ${ }^{(14-17)}$. The understanding of the regulation of muscle cellularity by specific nutrients in fish fed to apparent satiety is fragmentary: only a few nutritional conditions have been tested, and they have been tested in a limited number of species at different growth stages. In first-feeding larvae, the cellularity of white axial skeletal muscle has been successively demonstrated as being regulated by dietary protein sources in common carp and pikeperch ${ }^{(18,19)}$, by dietary DHA:EPA ratio in Atlantic $\operatorname{cod}^{(20)}$, by dietary lecithin source in gilthead sea bream ${ }^{(21)}$ and by dietary cholecalciferol content in European sea bass ${ }^{(22)}$. In fingerlings, white muscle cellularity has been shown to be sensitive to the form of delivery of lysine and glycine in common carp $^{(23)}$. During the subsequent period of life (i.e. juvenile life), the cellularity of white muscle has been shown to vary according to dietary lipid source in rainbow trout ${ }^{(24)}$, protein level in Atlantic salmon and blackspot sea bream ${ }^{(25-27)}$, and protein sources and amino acid profile in rainbow trout ${ }^{(28,29)}$. To our knowledge, no information on the effects of dietary lipid levels on muscle cellularity (which is a phenotypic consequence of muscle hyperplasia and hypertrophy) in fish is currently available.

The first aim of the present study was to characterise the ontogenetic changes in the expression of genes that regulate early myogenesis in trout and to characterise the corresponding changes in muscle cellularity. The genes selected were myogenic regulatory factors (MRF; myogenic differentiation 1 (MyoD1), myogenic factor 5 (Myf5) and myogenin (Myog)), a marker of cell proliferation (proliferating cell nuclear antigen $(P C N A)$ ) and involved in muscle structure and function (fast myosin heavy chain (fast-MHC) and slow myosin heavy chain (slow-MHC)). The second aim of the study was to determine how an early decrease in dietary protein: energy ratio by fat addition regulates muscle growth and its mechanisms (hyperplasia and hypertrophy) in rainbow trout alevins by means of histological and molecular analyses. The third aim of the study was to determine whether an early decrease in dietary protein: energy ratio by fat addition (i.e. early feeding with a high-fat (HF) diet instead of a low-fat (LF) diet) had a long-term effect on the subsequent muscle growth processes of juveniles fed a commercial diet.

\section{Experimental methods}

\section{Growth experiment and sampling procedures}

The eggs of diploid rainbow trout (O. mykiss) were obtained in February from a commercial fish farm (Viviers de France) and incubated/reared in an INRA experimental fish farm (Lees-Athas, France) in spring water at a temperature range of 7.5 to $8.4^{\circ} \mathrm{C}$. Embryos were sampled at the eyed stage (270 degree days post-fertilisation $\left({ }^{\circ} \mathrm{d}\right)$ ). Alevins were sampled at hatching $\left(333^{\circ} \mathrm{d}\right)$, first exogenous feeding $\left(528^{\circ} \mathrm{d}\right)$, yolk-sac resorption $\left(602^{\circ} \mathrm{d}=10 \mathrm{~d}\right.$ of feeding (df)), and after $30 \mathrm{df}$ $\left(758^{\circ} \mathrm{d}\right), 60 \mathrm{df}\left(992^{\circ} \mathrm{d}\right), 75 \mathrm{df}\left(1109^{\circ} \mathrm{d}\right)$ and $90 \mathrm{df}\left(1226^{\circ} \mathrm{d}\right)$ with the experimental diets. To characterise early myogenesis and its regulation by a HF diet from first feeding onwards accurately, eggs and alevins of rainbow trout were subjected to three successive gradings. The first grading was a size grading that was performed at the embryonic eyed stage. This grading was performed because egg size significantly affects both yolk utilisation and early body growth in rainbow trout ${ }^{(30,31)}$. Therefore, the eggs used in the present study were sorted with grids and those with diameters $<4.8$ or $>5.4 \mathrm{~mm}$ were discarded, in order to retain an egg population with a mean diameter of $5 \cdot 1 \mathrm{~mm}$. The two subsequent gradings were developmental grading, in order to work on the best possible 'developmentally coordinated' population of alevins. The first developmental grading was applied at hatching. As hatching lasted $6 \mathrm{~d}$ in the study conditions $\left(7 \cdot 5-8 \cdot 4^{\circ} \mathrm{C}\right)$, the alevins that hatched from the 2 nd to the 4 th day of hatching were retained, and those that hatched earlier and later were discarded. The 'hatching' stage that was sampled corresponded to the peak of hatching $\left(333^{\circ} \mathrm{d}\right)$. The alevins of rainbow trout hatch with important yolk reserve, and they develop on these endogenous reserves until they 'emerge' from the river substrate in the natural environment/tank bottom in aquaculture conditions to search for exogenous food. The alevins emerge before the complete resorption of their yolk reserve and their development thus relies on 'mixed' feeding (endogenous reserves + exogenous food) until complete yolk-sac resorption. The second developmental grading applied was at emergence, in order to homogenise the 'first exogenous feeding stage' of alevins. As emergence in rainbow trout lasts numerous days at the conditions of 7.5 to $8 \cdot 4^{\circ} \mathrm{C}$, the alevins that emerged 'precociously' (during the first $3 \mathrm{~d}$ of emergence) were discarded; those that emerged between the 4th and the 6th day were sorted daily and fed immediately to satiety with the experimental diets, and those emerging later were discarded. This schedule was applied in order to avoid the negative effect of delayed feeding on early body growth in trout ${ }^{(31)}$. It was also verified that the alevins sampled at the 'yolk-sac resorption' stage $\left(602^{\circ} \mathrm{d}\right)$ were totally free of macroscopically visible remaining yolk reserves.

The following two successive feeding trials were conducted: the first trial was conducted with two experimental diets from first feeding onwards to assess the effects of an early decrease in dietary protein:energy ratio by the addition of lipids on the muscle growth mechanisms of alevins, and the second trial was conducted in juveniles fed with a commercial diet to assess whether the changes in early nutritional 
conditions tested had a long-term effect on the muscle growth of trout (Fig. 1).

For the first trial, two experimental diets were formulated to contain the same level of protein and different dietary protein: energy ratios (Table 1). The common basis was made of fishmeal and extruded pea as protein sources, sodium alginate, and vitamin mix and mineral mix in order to meet the nutritional requirements of trout fry. In the HF diet, non-protein energy was mainly supplied by fish oil, and in the LF diet, fish oil was replaced by crude wheat starch. The ingredients were mixed and the mixture was processed as food particles of different diameters to match the increasing mouth size of the alevins. The analytical composition of the two diets was assessed using the following procedures: DM was assessed after drying at $105^{\circ} \mathrm{C}$ for $24 \mathrm{~h}$; protein content $(\mathrm{N} \times 6.25)$ was determined by the Kjeldahl method; fat level was assessed by weighing before and after petroleum diethyl ether extraction (Soxtherm, Gerhardt); starch content was determined according to the method described by Thivend et al. ${ }^{(32)}$; gross energy content was determined after combustion in an adiabatic bomb calorimeter. Protein content was found to be high and similar in the two diets $(60 \cdot 3 v$ v $61.6 \% \mathrm{DM})$. Energy content was found to be higher in the HF diet $(23.2 \mathrm{~kJ} / \mathrm{g}$ dry weight) than in the LF diet $(20.3 \mathrm{~kJ} / \mathrm{g}$ dry weight) due to the higher lipid content of the HF diet (20\%) than that of the LF diet (6.8\%), as shown in Table 1.

The HF and LF diets were distributed from emergence (first exogenous feeding $=$ day 0 of the feeding trial) onwards to triplicate groups of 3200 alevins that were hand-fed six times per $\mathrm{d}$ to excess or visual satiety. At $75 \mathrm{df}$, the alevins were sorted. Three replicates of 1400 alevins from the HF diet-fed group were fed a commercial diet (17\% crude lipids, 54\% crude protein and $22.5 \mathrm{~kJ} / \mathrm{g}$ DM, Ecostart 18; BioMar). The alevins from the LF diet-fed group were divided into six replicates of 1400 fish: three replicates were fed the commercial diet, while the other three replicates were maintained on the LF diet until they reached the weight of HF diet-fed fish at $75 \mathrm{df}, 15 \mathrm{~d}$ later. The groups transferred to the commercial diet at $75 \mathrm{df}$ were fed to satiety for 3 months with this diet. Thereafter, rearing of the initially LF diet-fed juveniles was continued until they reached the same weight $(+16 \mathrm{~d})$ as that of the initially HF diet-fed fish after 3 months of feeding ( $\mathrm{mf}$ ) with the commercial diet. Juveniles were sampled after $3 \mathrm{mf}$ and $3 \mathrm{mf}+16 \mathrm{df}$ with the commercial diet.
These sampling schedules (Fig. 1) were constructed in order to compare the alevins and juveniles not only at a similar age but also at a similar body size.

For the analysis of the expression levels of muscle growth-related genes, samples were pools of whole (yolk sac-removed) embryos at the eyed stage and alevins at hatching; pools of 'trunks' (posterior body part without the viscera, from the anterior insertion of the dorsal fin to the vent; Fig. 3(A)) from first feeding to $90 \mathrm{df}$; and individual pieces of dorsal white muscle of juveniles. These samples were immediately frozen in liquid $\mathrm{N}_{2}$ and stored at $-80^{\circ} \mathrm{C}$ until molecular analysis. For analysis of muscle cellularity, ten fish were sampled per batch. These histological samples (whole alevins at first feeding and at 30, 75 and $90 \mathrm{df}$; transverse sections of $1 \mathrm{~cm}$ width cut at the vent level of previously weighed and measured juveniles), were fixed and dehydrated according to the method described by AlamiDurante et $a l^{(12)}$ until further histological analysis. For the qualitative histochemical determination of the location of lipid deposits, whole alevins were individually sampled after $75 \mathrm{df}$, frozen in liquid $\mathrm{N}_{2}$ and stored at $-80^{\circ} \mathrm{C}$. Other alevins were frozen in liquid $\mathrm{N}_{2}$ at $75 \mathrm{df}$ (fifteen pools of three (HF) or four to five (LF) alevins) and $90 \mathrm{df}$ (eight pools of two to three (LF) whole alevins) for quantification of lipid content in the whole body, and at $75 \mathrm{df}$ for quantification of the lipid content of the trunk compared with the remaining part of the anterior body (three pools of five alevins/body part per diet). The experiment was conducted according to the Guidelines of the National Legislation on Animal Care of the French Ministry of Research and complied with European Community Directive 86/609/EEC.

\section{Quantification and histochemical location of lipid deposits}

Lipid deposits in the whole body, trunk and anterior part of the frozen alevins were quantified according to the method of Folch et $a l .{ }^{(33)}$. For histochemical location of lipid deposits, other frozen alevins were cut transversely at $-25^{\circ} \mathrm{C}$ in slices of $10 \mu \mathrm{m}$ thick at two anatomical levels, namely the level of the anterior insertion of the dorsal fin (anterior body level) and the level of the vent (tail level), as shown in Fig. 3(B). Lipid deposits were stained with dark Sudan Black $^{(34)}$ on just a few alevins, to obtain qualitative information on the location of lipid deposits in muscle.

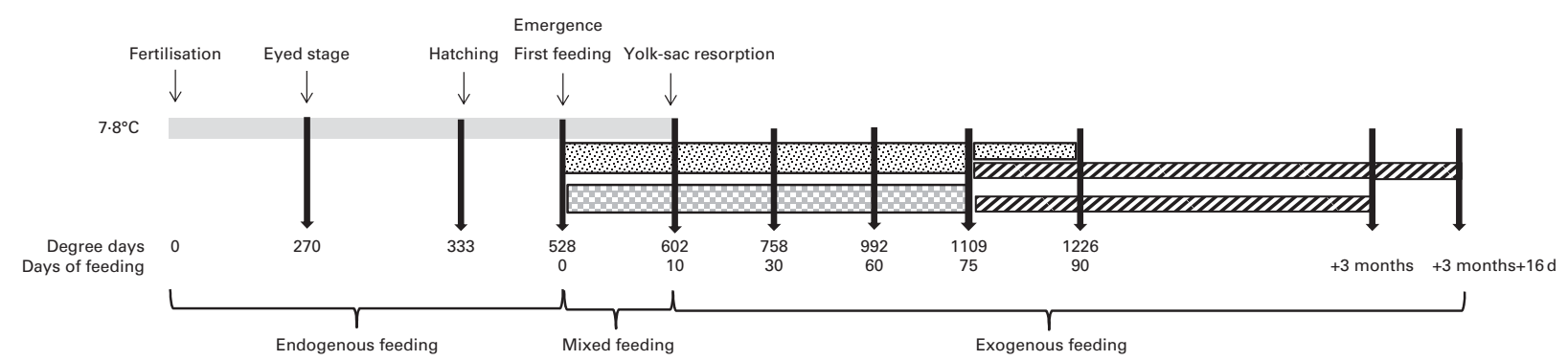

Fig. 1. Schematic diagram of the feeding trials with changes in nutritional conditions and sampling stages/ages (arrows) with corresponding degree days from fertilisation and days of exogenous feeding. $\square$, Yolk reserves; 圈, low-fat diet; $⿴ 囗 ⿱ 一 一$, , high-fat diet; $\square$, commercial diet. 
Table 1. Ingredients and analytical composition of the experimental diets

\begin{tabular}{|c|c|c|}
\hline & LF diet & HF die \\
\hline \multicolumn{3}{|l|}{ Ingredients ( $\mathrm{g} / \mathrm{kg}$ diet) } \\
\hline Fishmeal $^{*}$ & $786 \cdot 4$ & 786.4 \\
\hline Peast & $50 \cdot 9$ & 50.9 \\
\hline Crude wheat starch $\ddagger$ & $122 \cdot 7$ & 0.0 \\
\hline Fish oil* & 0.0 & $122 \cdot 7$ \\
\hline Sodium alginate§ & $20 \cdot 0$ & $20 \cdot 0$ \\
\hline Mineral mix & $10 \cdot 0$ & $10 \cdot 0$ \\
\hline Vitamin mix & $10 \cdot 0$ & $10 \cdot 0$ \\
\hline \multicolumn{3}{|l|}{ Analytical composition } \\
\hline Proteins $(N \times 6.25)(\%$ dry weight $)$ & 61.6 & $60 \cdot 3$ \\
\hline Lipids ( $\%$ dry weight) & $6 \cdot 8$ & $20 \cdot 0$ \\
\hline Starch (\% dry weight) & 14.8 & 3.4 \\
\hline Energy (kJ/g dry weight) & $20 \cdot 3$ & $23 \cdot 2$ \\
\hline Protein:energy $(\mathrm{mg} / \mathrm{kJ})$ & 30.3 & $26 \cdot 0$ \\
\hline
\end{tabular}

$L F$, low fat; $H F$, high fat.

* Sopropèche, France.

† Sotexpro, France.

$\ddagger$ Roquette, France.

$\S$ Ets Louis François, France.

II CM 762, INRA, France.

I CV 763, INRA, France.

\section{Quantitative histological analysis}

Alevins kept in butanol were weighed and measured. The tails were then cut, dehydrated, embedded in paraffin and cut transversely into sections $(10 \mu \mathrm{m}$ thick) that were stained with haematoxylin and orange $G$ as described in AlamiDurante et $a l .{ }^{(12)}$. The sections of juveniles were similarly paraffin embedded, cut and stained. Muscle cellularity was examined on one section per fish, located at the vent level. The total cross-sectional areas of white and red muscles and the individual cross-sectional areas of white muscle fibres were quantified with Optimas software (Media Cybernetics). To quantify stratified and mosaic hyperplasia, and maximum hypertrophy and to measure the numbers of muscle fibres greater than 500 fibres in all fish, white muscle cellularity was studied in three whole sections of myotomes at first feeding, two whole sections of myotomes at $30 \mathrm{df}$, one whole section of myotomes at 75 and $90 \mathrm{df}$, and a transverse section of a myotome in juveniles. The individual equivalent diameter of white muscle fibres (diameter of a circle of equal area to that of the muscle fibre, hereafter referred to as 'fibre diameter') was determined. The total number of white muscle fibres was estimated from the total cross-sectional area of white muscle and the mean cross-sectional area of white muscle fibres. Cellularity was analysed in seven alevins at first feeding, nine alevins at $30 \mathrm{df}$ (HF and LF diets), $75 \mathrm{df}$ (HF and LF diets) and $90 \mathrm{df}$ (LF diet), and six to ten juveniles per condition.

\section{RNA extraction and quantitative RT-PCR}

Total RNA was extracted using TRIzol ${ }^{\circledR}$ reagent (Invitrogen), according to the manufacturer's instructions, and stored in nuclease-free water (Dutscher) at $-20^{\circ} \mathrm{C}$ ( $n$ 5-11 pools/condition). Samples were subjected to electrophoresis on $1 \%$ agarose gels to confirm the integrity of $28 \mathrm{~S}$ and 18S rRNA bands, and RNA purity was assessed by the absorbance ratio of $260: 280 \mathrm{~nm}$, with the ratio ranging between 1.7 and $2 \cdot 1$ being acceptable. RNA integrity was verified using an Agilent Technologies method (Agilent 2100 Bioanalyzer and RNA 6000 Nano LabChip kit). Published primers were used to quantify the expression of skeletal fast-MHC ${ }^{(28)}$, slow-MHC ${ }^{(28)}$, MyoD1 ${ }^{(28)}, P C N A^{(28)}, \operatorname{Myog}^{(35)}$ and $18 S^{(36)}$ mRNA. Primers were designed for $M y f 5$ (forward gcttaccttctcgccctcca; reverse tcaaagcggtatgcggttga) using GeneBank sequence AY751283.1 and primer 3 software (University of Massachusetts). All primers were synthesised by Eurogentec and amplicons confirmed by sequencing (Millegen). Complementary DNA (cDNA) was generated from $2 \mu \mathrm{g}$ of total RNA using $200 \mathrm{U}_{\text {SuperSript }}{ }^{\mathrm{TM}}$ III Reverse Transcriptase (Invitrogen) and $500 \mathrm{ng}$ random primers (Promega) in a total volume of $20 \mu \mathrm{l}$. RNA samples were heated at $25^{\circ} \mathrm{C}$ for $10 \mathrm{~min}$, at $65^{\circ} \mathrm{C}$ for $3 \mathrm{~min}$, and then at $55^{\circ} \mathrm{C}$ for $1 \mathrm{~h}$ to generate cDNA, followed by heat inactivation at $70^{\circ} \mathrm{C}$ for $15 \mathrm{~min}$. Real-time PCR was performed in an iCycler $\mathrm{iQ}^{\mathrm{TM}}$ (Bio-Rad) on duplicates of each $\mathrm{RT}$ product using the $\mathrm{iQ}^{\mathrm{TM}}$ SYBR $^{\circledR}$ Green Supermix (Bio-Rad). All PCR assays were set up using $200 \mathrm{nmol} / \mathrm{l}$ of each primer and $10 \mu \mathrm{l} \mathrm{cDNA}$ (diluted at 1:30 except for $18 S$ and fast-MHC (at 1:120)) in a reaction volume of $25 \mu \mathrm{l}$. Overall, thirty-five steps of PCR were performed, each consisting of heating at $95^{\circ} \mathrm{C}$ for $20 \mathrm{~s}$ to denature cDNA, and at the annealing temperature for $30 \mathrm{~s}$ for polymerisation. Following the final cycle of PCR, melting curves were systematically monitored (increasing the set-point temperature from 55 to $94^{\circ} \mathrm{C}$ by $0.5^{\circ} \mathrm{C} / 10 \mathrm{~s}$ ) to confirm the production of a single product and for dissociation analysis of the PCR products. Controls were included to test the absence of contamination by genomic DNA or assay reagents. Standard curves, consisting of five serial dilutions in triplicate of a pool of cDNA, were obtained for each cDNA template by plotting $C_{\mathrm{T}}$ values against the $\log _{10}$ of the different dilutions. Real-time PCR efficiency was calculated from standard curves according to the method described by Pfaffl ${ }^{(37)}$. Abundance of 18S RNA was similar for all conditions and was used for the normalisation of quantitative PCR data. The 18 S-adjusted data were analysed using the $\Delta \Delta C_{\mathrm{T}} \operatorname{method}^{(37)}$, with the first-feeding stage as the control for alevins and the initially LF diet-fed juveniles after $3 \mathrm{mf}$ with the commercial diet as the control for juveniles.

\section{Statistical analysis}

Data that were ln transformed (weight, total length, total cross-sectional area of white and red muscles and white muscle fibre diameters), arcsine transformed (percentage of white muscle fibres in a diameter class) or square root transformed (total number of white muscle fibres) were analysed by ANOVA and Student-Newman-Keuls tests with R 2.15.3 software (University of Auckland). ANOVA were performed on pools of embryos, alevins or trunks (relative gene expression levels and lipid deposits) or on individuals (muscle fibre diameters). Results for cellularity were compared both at three equivalent durations of the feeding period (30 and $75 \mathrm{df}$ with the HF and LF diets, and $3 \mathrm{mf}$ with the commercial diet) and, as white muscle cellularity is size dependent in trout and 


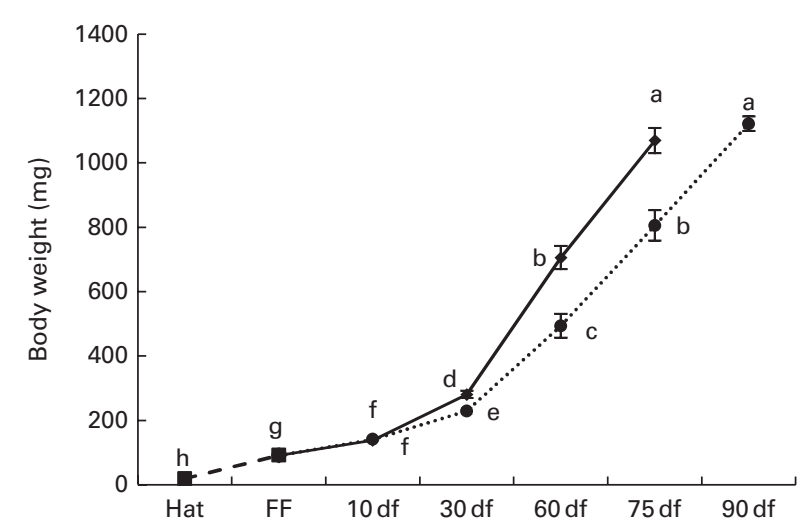

Fig. 2. Body growth of rainbow trout alevins fed the high-fat $(\bullet-)$ and low-fat (...) diets from first feeding onwards. Values are means, with their standard errors represented by vertical bars. ${ }^{\mathrm{a}, \mathrm{b}, \mathrm{c}, \mathrm{d}, \mathrm{e}, \mathrm{f}, \mathrm{g}, \mathrm{h}}$ Mean values with unlike letters were significantly different $(P<0.0001)$. Hat, hatching; FF, first exogenous feeding; df, days of feeding. - - Endogenous feeding.

other teleosts $^{(7,38)}$, at a similar body size (HF diet-fed alevins after $75 \mathrm{df} v$. LF diet-fed alevins after $90 \mathrm{df}$; initially HF diet-fed juveniles after $3 \mathrm{mf}$ with the commercial diet $v$. initially LF diet-fed juveniles after $3 \mathrm{mf}+16 \mathrm{df}$ with the commercial diet). A $P$ value of 0.05 was considered as statistically significant. Data are presented as means with their standard errors.

\section{Results}

\section{Somatic growth of alevins and juveniles}

During the first $10 \mathrm{df}$, no significant differences were observed in the increase of the body weight of rainbow trout alevins (Fig. 2) . Later, the alevins fed the HF diet showed significantly increased body weight compared with those fed the LF diet; from $60 \mathrm{df}$ onwards, LF diet-fed alevins reached the weight of HF diet-fed alevins at an interval of $15 \mathrm{~d}(P<0 \cdot 0001)$.

The body weights and total lengths of the initially HF dietfed juveniles after $3 \mathrm{mf}$ with the commercial diet $(P=0.0394$ and $P=0.020$, respectively) were significantly higher than those of the initially LF diet-fed juveniles after $3 \mathrm{mf}$ with the commercial diet, but were, as planned in the protocol, similar to those of the initially LF diet-fed juveniles after $3 \mathrm{mf}+16 \mathrm{df}$ with the commercial diet (Table 3).

\section{Lipid content of alevins and location of lipid deposits}

As shown in Fig. 3(A), the bodies of HF diet-fed alevins contained $84 \%$ more lipids than those of LF diet-fed alevins after $75 \mathrm{df}$ $(P<0.001)$. The body lipid content of HF diet-fed alevins at $75 \mathrm{df}$ was also about twice as high as that of LF diet-fed alevins of similar body weight, because the total lipid content of LF diet-fed alevins did not increase between 75 and $90 \mathrm{df}(P=0.575)$.

The comparison of the lipid content of the anterior part of alevins with that of the trunk part first showed that in both LF diet-fed $(P=0.017)$ and HF diet-fed $(P=0.0019)$ alevins, more lipids were deposited in the anterior part than in the trunk (LF diet $+46 \%$; HF diet $+58 \%$ ). It also showed that the distribution of the HF diet, not the LF diet, significantly increased the quantity of lipids deposited in both the anterior part $(P=0.001)$ and the trunk $(P=0.025)$ of alevins. The histochemical staining of lipids confirmed that more lipids were deposited in HF diet-fed than in LF diet-fed alevins, and that these lipids were mainly deposited in the anterior part, around the viscera (data not shown). As shown in Fig. 3(B), lipids were also deposited in red muscle and in specific areas of white muscle. In the white muscle of $\mathrm{HF}$ diet-fed alevins, lipids were mainly deposited in the apical area (A1), the deep area close to the spinal cord (A2) and the abdominal area, close to the pyloric caeca (A4).

\section{Growth dynamics of white and red axial skeletal muscles}

As shown in Table 2, feeding the alevins with the HF diet from first feeding onwards had no effect on the total cross-sectional area of white muscle at $30 \mathrm{df}\left(758^{\circ} \mathrm{d}\right)$; however, it significantly increased the total cross-sectional area of white muscle at $75 \mathrm{df}\left(1109^{\circ} \mathrm{d}\right)$, without reaching the total cross-sectional area of white muscle observed in LF diet-fed alevins of similar body size, i.e. at $90 \mathrm{df}$ $\left(1226^{\circ} \mathrm{d} ; \quad P<0 \cdot 0001\right)$. The total cross-sectional area of red muscle was not significantly different in HF diet- and LF diet-fed alevins at 30 and $75 \mathrm{df}$; however, it was lower in HF diet-fed alevins at $75 \mathrm{df}$ than in LF diet-fed alevins of similar body size, i.e. at $90 \mathrm{df}(P<0.0001)$. The total number of white muscle fibres increased with days of feeding $(P<0 \cdot 0001)$; however, it was not significantly affected by dietary lipid content. The mean diameter of white muscle fibres increased between first feeding $\left(528^{\circ} \mathrm{d}\right)$ and $75 \mathrm{df}(P<0 \cdot 0001)$ but remained constant thereafter. The median diameter of white muscle fibres increased from first feeding to $75 \mathrm{df}$ but decreased thereafter $(P<0 \cdot 0001)$. The maximum diameter of white muscle fibres increased from first feeding to $90 \mathrm{df}(P<0 \cdot 0001)$.

The shape of the distribution of white muscle fibre diameters changed with time: it was unimodal at first feeding, bimodal at 30 and $75 \mathrm{df}$, before returning to unimodality at $90 \mathrm{df}$ (Fig. 4(A)). The percentage of white muscle fibres constituting the first mode $(10-15 \mu \mathrm{m})$ of the distribution of white muscle fibre diameters decreased between first feeding and $75 \mathrm{df}$ and increased between 75 and $90 \mathrm{df}$, up to the value observed at $30 \mathrm{df}(P<0 \cdot 0001)$. White muscle fibres with diameters $>30 \mu \mathrm{m}$ appeared after first feeding. The percentages of white muscle fibres constituting the diameter classes $30-35 \mu \mathrm{m}$ and $35-40 \mu \mathrm{m}$ increased between 30 and $75 \mathrm{df}$ and decreased between 75 and $90 \mathrm{df}$ ( $P<0.0001$ for both classes). Fibres with diameters $>40 \mu \mathrm{m}$ appeared at $75 \mathrm{df}$ and their percentages increased between 75 and $90 \mathrm{df}(40-45 \mu \mathrm{m}: P<0 \cdot 0001$; 45-50 $\mu \mathrm{m}: P<0.0001 ; 50-55 \mu \mathrm{m}: P<0.0002)$. The decrease in dietary protein:energy ratio resulting from the addition of lipids slightly affected the distribution of white muscle fibres at $30 \mathrm{df}$ (Fig. 4(B)) without significantly modifying the mean, median and maximum diameters of white muscle fibres (Table 2), or the percentages of white muscle fibres constituting the different diameter classes (Fig. 4(B)). Significant effects of dietary lipid levels on muscle cellularity were recorded in older fish (Table 2). The distribution of white muscle fibre diameters in HF diet-fed alevins at $75 \mathrm{df}$ was intermediate between that of LF diet-fed alevins at 75 and $90 \mathrm{df}$ (Fig. 4(C)), with significant differences between the batches of alevins in terms of the percentage of white muscle fibres in the diameter class constituting 
(A)

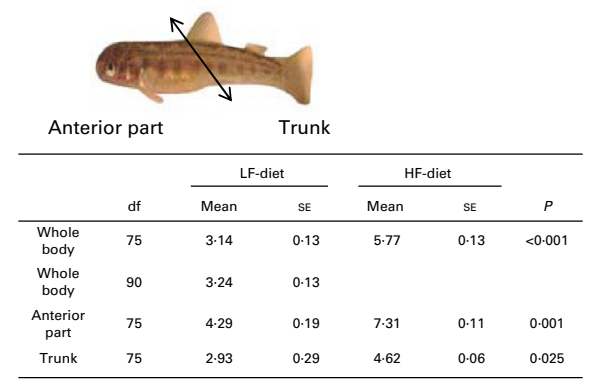

(B)
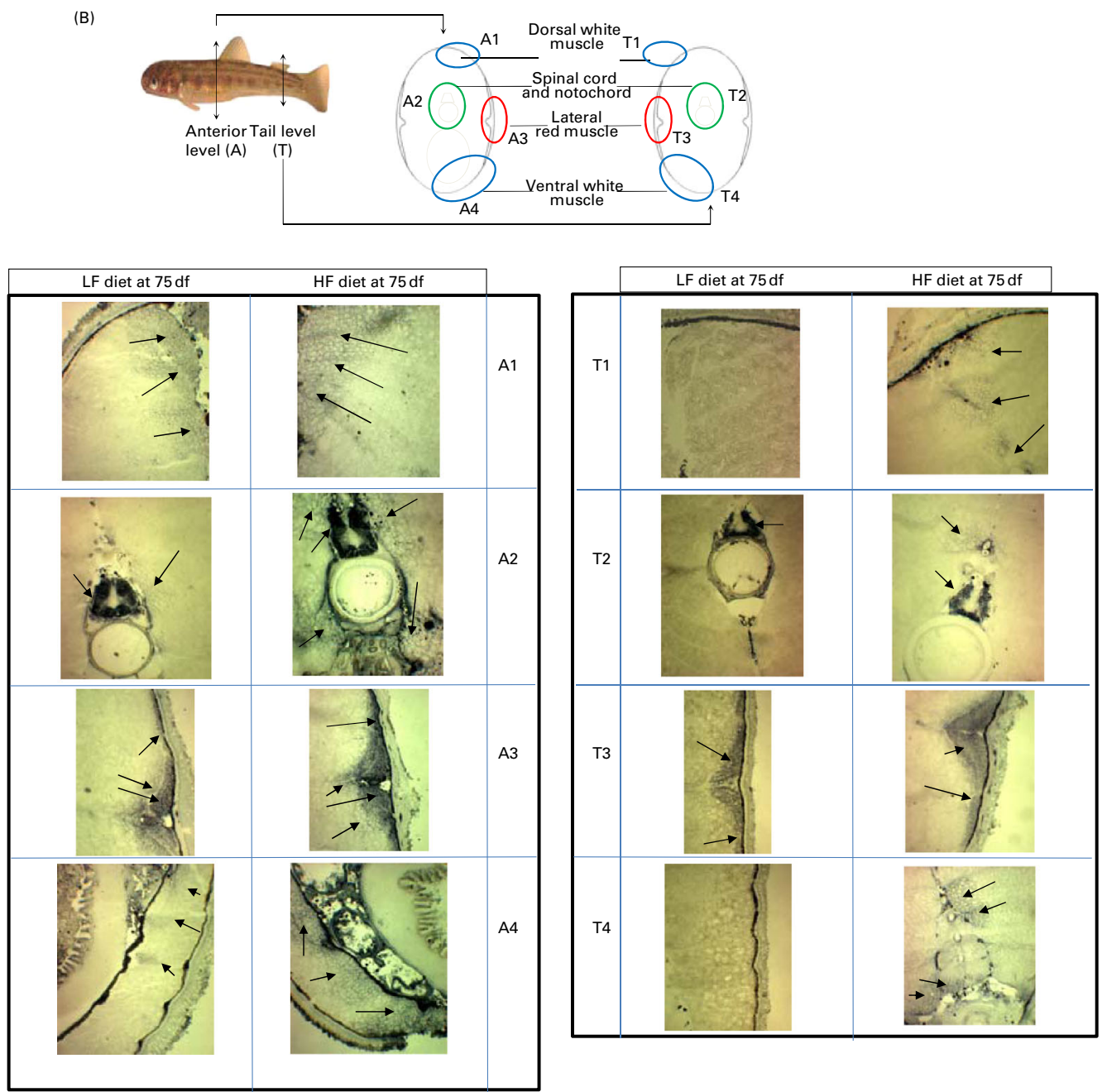

Fig. 3. (A) Quantification of lipid deposits (\% fresh weight) in the whole body, trunk and anterior part of alevins. Data presented in the table are mean values with their standard errors. (B) Anatomical positions of the two sections and four areas selected for visualising the tissular location of lipid deposits by Sudan Black histochemistry. The arrows indicate lipid deposits in white and red muscles. df, Days of feeding; LF, low fat; HF, high fat. A colour version of this figure can be found online at http://www.journals.cambridge.org/bjn

the mode $(10-15 \mu \mathrm{m})$ of the first population of muscle fibres $(P=0 \cdot 014)$, in terms of the percentage of white muscle fibres in the diameter class constituting the mode $(30-35 \mu \mathrm{m})$ of the second population of muscle fibres $(P=0.0003)$ and in the percentage of large white muscle fibres with diameters ranging between 45 and $50 \mu \mathrm{m}(P=0.0066)$. The maximum diameter of white muscle fibres (Table 2) and the percentage of white muscle fibres in the largest class of diameters (Fig. 4(C)) were both significantly higher in LF diet-fed alevins at $90 \mathrm{df}$ than in HF diet- and LF diet-fed alevins at $75 \mathrm{df}$.

Early feeding conditions had consequences on the subsequent white muscle growth processes in juveniles. After $3 \mathrm{mf}$ with the commercial diet, the total cross-sectional area of white muscle of the fish transferred to the commercial feed at $75 \mathrm{df}$ continued to be smaller in initially LF diet-fed juveniles than in initially HF diet-fed juveniles (Table 3). The distributions 
Table 2. Changes in the white muscle cellularity of rainbow trout alevins during the first $90 \mathrm{~d}$ of feeding (df) with the high-fat (HF) and low-fat (LF) diets (Mean values with their standard errors)

\begin{tabular}{|c|c|c|c|c|c|c|c|c|c|c|c|c|c|}
\hline & \multicolumn{2}{|c|}{ First feeding } & \multicolumn{2}{|c|}{ LF diet at $30 \mathrm{df}$} & \multicolumn{2}{|c|}{ HF diet at $30 \mathrm{df}$} & \multicolumn{2}{|c|}{ LF diet at $75 \mathrm{df}$} & \multicolumn{2}{|c|}{ HF diet at $75 \mathrm{df}$} & \multicolumn{2}{|c|}{ LF diet at $90 \mathrm{df}$} & \multirow[b]{2}{*}{$P$} \\
\hline & Mean & SE & Mean & SE & Mean & SE & Mean & SE & Mean & SE & Mean & SE & \\
\hline \multicolumn{14}{|c|}{ Total cross-sectional area $\left(\mathrm{mm}^{2}\right)$} \\
\hline White muscle & $0.307^{\mathrm{e}}$ & 0.022 & $0.687^{d}$ & 0.037 & $0.656^{d}$ & 0.035 & $1.694^{c}$ & 0.143 & $2.083^{b}$ & 0.098 & $2.937^{\mathrm{a}}$ & 0.085 & $<0.0001$ \\
\hline Red muscle & $0.015^{d}$ & 0.001 & $0.026^{c}$ & 0.003 & $0.033^{c}$ & 0.003 & $0.091^{\mathrm{b}}$ & 0.014 & $0 \cdot 114^{b}$ & 0.011 & $0 \cdot 172^{\mathrm{a}}$ & 0.005 & $<0.0001$ \\
\hline $\begin{array}{l}\text { Total number of } \\
\text { white muscle fibres }\end{array}$ & $1349^{d}$ & 52 & $2400^{c}$ & 146 & $2148^{\mathrm{C}}$ & 65 & $3634^{b}$ & 362 & $4245^{b}$ & 204 & $6744^{\mathrm{a}}$ & 413 & $<0.0001$ \\
\hline \multicolumn{14}{|c|}{ Diameter of white muscle fibres $(\mu \mathrm{m})$} \\
\hline Mean & $16 \cdot 98^{c}$ & 0.56 & $19 \cdot 18^{b}$ & 0.48 & $19 \cdot 69^{b}$ & 0.47 & $24 \cdot 65^{a}$ & 0.87 & $25 \cdot 09^{a}$ & $0 \cdot 70$ & $23 \cdot 76^{a}$ & 0.71 & $<0.0001$ \\
\hline Median & $17 \cdot 33^{c}$ & 0.58 & $20 \cdot 07^{b}$ & 0.54 & $20 \cdot 69^{b}$ & 0.70 & $25 \cdot 45^{\mathrm{a}}$ & 1.07 & $24 \cdot 33^{a}$ & 0.79 & $21 \cdot 50^{b}$ & 0.90 & $<0.0001$ \\
\hline Maximum & $28 \cdot 91^{\mathrm{e}}$ & 0.42 & $34.46^{\mathrm{d}}$ & 1.00 & $34.92^{d}$ & 0.87 & $44 \cdot 24^{c}$ & $1 \cdot 23$ & $47 \cdot 83^{b}$ & 1.64 & $53.05^{a}$ & $1 \cdot 11$ & $<0.0001$ \\
\hline \multicolumn{14}{|l|}{ Body characteristics } \\
\hline Weight (mg) & $100 \cdot 9^{d}$ & $3 \cdot 1$ & $229 \cdot 0^{c}$ & 11.4 & $280 \cdot 6^{c}$ & 11.6 & $805 \cdot 7^{b}$ & $47 \cdot 1$ & $1069 \cdot 7^{\mathrm{a}}$ & $39 \cdot 2$ & $1092 \cdot 5^{a}$ & 23.4 & $<0.0001$ \\
\hline Total length (mm) & $24 \cdot 2^{d}$ & 0.3 & $31 \cdot 1^{c}$ & 0.5 & $32 \cdot 0^{\mathrm{C}}$ & 0.4 & $47 \cdot 2^{b}$ & $6 \cdot 8$ & $50 \cdot 3^{a}$ & 0.7 & $48 \cdot 7^{\mathrm{a}, \mathrm{b}}$ & 0.4 & $<0.0001$ \\
\hline
\end{tabular}

a,b,c,d,e Mean values within a row with unlike superscript letters were significantly different $(P<0.05)$.

of white muscle fibre diameters in initially HF diet- and LF dietfed juveniles were very similar (Fig. 4(D)), as were the mean, median and maximum diameters of white muscle fibres (Table 3). Differences in muscle growth mechanisms were evidenced when juveniles were compared at similar body size (initially $\mathrm{HF}$ diet-fed juveniles after $3 \mathrm{mf}$ with the commercial diet $v$. initially LF diet-fed juveniles after $3 \mathrm{mf}+16 \mathrm{df}$ with the commercial diet): the mean diameter of white muscle fibres, the median diameter of white muscle fibres and the number of white muscle fibres with diameters ranging between 70 and $80 \mu \mathrm{m}$ were significantly higher $(P=0.047,0.030$ and 0.032 , respectively) in initially $\mathrm{LF}$ diet-fed juveniles than in initially HF diet-fed juveniles (Table 3; Fig. 4(D)).

\section{Expression of muscle growth-related genes}

Developmental regulation. As shown in Fig. 5 for the LF diet-fed batch, the relative expression levels of all the genes selected for the study were developmentally regulated. The expression of $M y f 5$ mRNA was stable between the eyed stage $\left(270^{\circ} \mathrm{d}\right)$ and first feeding $\left(528^{\circ} \mathrm{d}\right)$ and decreased between first feeding and $10 \mathrm{df}$ (yolk-sac resorption: $602^{\circ} \mathrm{d} ; P=0.0027$ ), but did not vary significantly thereafter. The expression of MyoD1 mRNA did not vary significantly between the eyed stage and hatching $\left(333^{\circ} \mathrm{d}\right)$ and increased between hatching and $10 \mathrm{df}(P=0.0252)$. The expression of PCNA mRNA was also not significantly different at the eyed stage and hatching, then decreased between the hatching and firstfeeding stages $(P<0 \cdot 0001)$ and did not change significantly thereafter. The expression of Myog mRNA decreased gradually between the eyed stage and first feeding $(P<0.0001)$, but did not change significantly thereafter. The expression of fast-MHC mRNA increased gradually between the eyed stage and $10 \mathrm{df}$, and increased between 30 and $75 \mathrm{df}(P<0.0001)$. The expression of slow-MHC mRNA increased significantly between the eyed stage and $10 \mathrm{df}$, and between 10 and $75 \mathrm{df}$ $(P<0 \cdot 0001)$.

Effects of early nutrition. As shown in Table 4, there was a significant effect observed in the very short term (10 df) and the short term ( $30 \mathrm{df}$ ) of the early decrease in dietary protein:energy ratio by the addition of lipids on the relative expression of fastMHC mRNA, with higher expression levels being shown at 10 and $30 \mathrm{df}$ in LF diet-fed alevins compared with HF diet-fed alevins ( $P=0.0383$ and 0.0018 , respectively). However, no significant effects of dietary lipid levels on the relative expression levels of slow-MHC, Myf5, MyoD1, Myog and PCNA mRNA at 10 and $30 \mathrm{df}$ were observed. There were also no significant effects of dietary lipid levels on the expression of fast-MHC, slow-MHC, Myf5, MyoD1 and Myog mRNA after $75 \mathrm{df}$ (Table 4), but comparison of alevins at similar body weights (i.e. LF diet-fed alevins at $90 \mathrm{df} v$. HF diet-fed alevins at $75 \mathrm{df}$ ) indicated that the relative expression of PCNA mRNA was significantly higher in the former than in the latter $(P=0 \cdot 0014)$.

Long-term effects of early nutrition after transfer to a common commercial diet at $75 d$ of feeding. A significant effect of an early decrease in dietary protein:energy ratio by the addition of lipids was recorded after $3 \mathrm{mf}$ with the commercial diet, with a significantly higher relative expression level of PCNA mRNA ( $P=0.0122)$ in juveniles initially fed the LF diet (Table 4). The comparison of juveniles at similar body weights (i.e. juveniles fed the HF diet for $75 \mathrm{~d}+$ the commercial diet for 3 months $v$. juveniles fed the LF diet for $75 \mathrm{~d}+$ the commercial diet for 3 months $+16 \mathrm{~d}$ ) revealed a significantly higher relative expression levels of MyoD1 $(P=0.0184)$ and Myog $(P=0.0019)$ mRNA in the latter than in the former (Table 4).

\section{Discussion}

\section{Ontogenetic changes in muscle growth dynamics and expression of muscle growth-related genes}

We characterised the ontogenetic changes occurring in the distribution of white skeletal muscle fibres during the first $90 \mathrm{df}$ of rainbow trout alevins and demonstrated the maintenance of a population of white muscle fibres of small diameter $(<20 \mu \mathrm{m})$, which indicated the persistent recruitment of new white muscle fibres. The changes in the percentage of these small fibres with time showed that the recruitment of new fibres decreased between 30 and $75 \mathrm{df}$, but increased between 

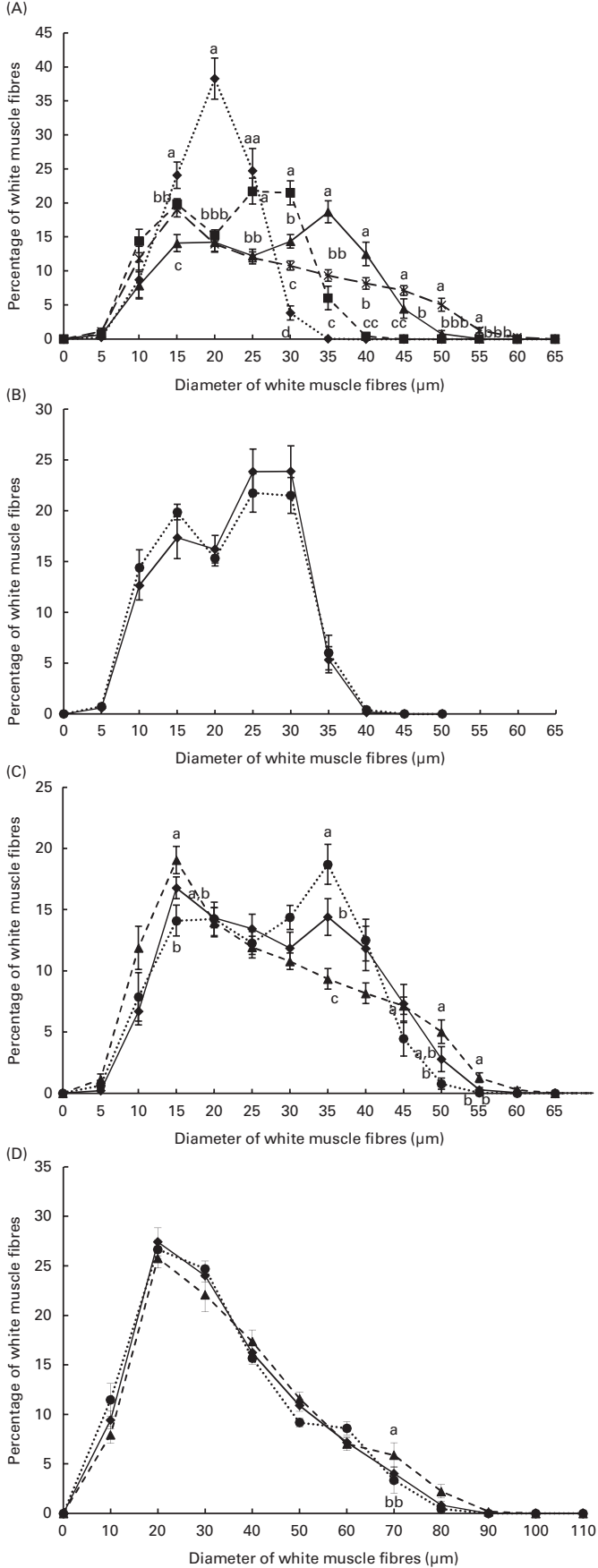

Fig. 4. Changes in the distribution of white muscle fibre diameters with age (A), according to dietary lipid levels at 30,75 and $90 \mathrm{~d}$ of initial feeding with the high-fat (HF) and low-fat (LF) diets (B, C), and after 3 months (m) and $3 m+16 d$ of additional feeding with the commercial diet (CD) (D). Values are means, with their standard errors represented by vertical bars. $a, b, c, d$ Mean values with unlike letters were significantly different in a diameter

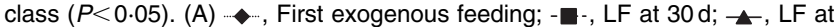
$75 \mathrm{~d} ;-*-$, LF at $90 \mathrm{~d}$. (B) - , HF at $30 \mathrm{~d} ; \cdots \cdots$, LF at $30 \mathrm{~d}$. (C) $\bullet-, \mathrm{HF}$ at $75 \mathrm{~d}$; - , LF at $75 \mathrm{~d}$; - - , LF at $90 \mathrm{~d}$. (D) $\bullet-$, HF at $75 \mathrm{~d}+\mathrm{CD}$ for $6 \mathrm{~m}$; $\bullet$, LF at $75 d+C D$ for $6 m$; - - , LF at $75 d+C D$ for $6 m$ and $16 d$

75 and $90 \mathrm{df}$, as confirmed by the changes in the total number of white muscle fibres. This showed that the contribution of hyperplasia to muscle growth changed during the growth of rainbow trout alevins, and confirmed the results of earlier studies $^{(7,8)}$. Myogenesis is regulated by a family of transcription factors called MRF that are expressed in a temporally distinct pattern during determination, activation and proliferation of muscle precursor cells ( $M y f 5$ and $M y o D)$ and in cells entering the terminal differentiation programme $(M y O g)^{(39)}$. Proliferative muscle precursor cells also express $P C N A$, which functions as a cofactor of DNA polymerase- $\delta$ and is necessary for cell-cycle progression and cell proliferation ${ }^{(40)}$. The present results demonstrated that $M y o D 1$ and $M y f 5$ are not similarly regulated during early muscle development in rainbow trout. Our findings of a high relative expression level of $M y f 5$ mRNA during embryonic endogenous feeding, which decreased between first feeding $\left(528^{\circ} \mathrm{d}\right.$ ) and $10 \mathrm{df}$ (yolk-sac resorption: $602^{\circ} \mathrm{d}$ ), and a low relative embryonic expression of MyoD1 mRNA, which increased between hatching and yolk-sac resorption, suggest a sequential significance of these two MRF during early myogenesis in trout. This is consistent with the changes in the expression levels of $M y f 5$ and $M y o D$ mRNA that occur during mammalian myogenic lineage progression ${ }^{(39)}$. The ontogenetic changes that we observed herein in rainbow trout between hatching $\left(333^{\circ} \mathrm{d}\right)$ and yolk-sac resorption $\left(602^{\circ} \mathrm{d}\right.$; $10 \mathrm{df})$ at the relative expression level of MyoD1 mRNA (increasing significantly) confirmed previous results obtained for the same species at $8^{\circ} \mathrm{C}^{(41)}$ and extended them by indicating that the relative expression of MyoD1 mRNA did not vary significantly during the subsequent $65 \mathrm{df}$ (i.e. up to $1109^{\circ} \mathrm{d}$ ). In contrast, others ${ }^{(42)}$ have reported a decrease in the relative expression of MyoD1 mRNA in trout alevins between $550^{\circ} \mathrm{d}$ (endogenous feeding) and $638^{\circ} \mathrm{d}$ (mixed feeding). This difference is probably linked to the fact that alevins were fed later (at only $638^{\circ} \mathrm{d}$ ) in the study of Mennigen et al. ${ }^{(42)}$, while in the present study, the first meal was distributed at $528^{\circ} \mathrm{d}$. The alevins in their study ${ }^{(42)}$ had probably suffered from this delay in first feeding, which might have impaired the myogenic process and thus lowered the relative expression of MyoD1 mRNA. A delay in first feeding had indeed already been demonstrated to have a negative effect on the body growth of rainbow trout alevins ${ }^{(31)}$, and the onset of exogenous feeding, by providing access to an unlimited source of nutrients and energy, is known to trigger myogenesis, and in particular hyperplasia, in different fish species ${ }^{(9,11,19,43)}$. Briefly, delayed first feeding $(2-3 \mathrm{~d})$ is also known to decrease myofibre area and induce myonuclear apoptosis in chickens ${ }^{(44)}$ and to decrease skeletal muscle growth, satellite cell proliferation and Myog mRNA expression in turkey poults ${ }^{(45)}$. The ontogenetic pattern of $M y o g$ mRNA expression that we observed between $270^{\circ} \mathrm{d}$ (eyed stage) and $602^{\circ} \mathrm{d}$ (yolk-sac resorption) was different from that reported by Johansen \& Overturf ${ }^{(46)}$ between 210 and $555^{\circ} \mathrm{d}$ for the same species. This might be linked to the differences in experimental temperatures $\left(7.5-8.4^{\circ} \mathrm{C}\right.$ in the present study $v .15^{\circ} \mathrm{C}$ in Johansen \& Overturf's study ${ }^{(46)}$, as some ontogenetic changes in the expression level of Myog mRNA are known to be temperature dependent in rainbow trout ${ }^{(41)}$. As in the latter study, we found that the expression level of fast-MHC mRNA increased in the alevins of rainbow trout between the hatching and yolk-sac resorption stages. In agreement with the increased expression levels of genes involved in muscle sarcomeric content (fast-MHC and 
Table 3. Changes in the white muscle cellularity of rainbow trout juveniles at the end of the commercial diet (CD) feeding period (Mean values with their standard errors)

\begin{tabular}{|c|c|c|c|c|c|c|c|}
\hline & \multicolumn{2}{|c|}{$\begin{array}{l}\text { Initially LF diet-fed + } \\
\text { CD for } 3 \text { months }\end{array}$} & \multicolumn{2}{|c|}{$\begin{array}{l}\text { Initially HF diet-fed }+ \\
\text { CD for } 3 \text { months }\end{array}$} & \multicolumn{2}{|c|}{$\begin{array}{l}\text { Initially LF diet-fed }+ \\
\text { CD for } 3 \text { months } \\
\text { and } 16 \mathrm{~d}\end{array}$} & \multirow[b]{2}{*}{$P$} \\
\hline & Mean & SE & Mean & SE & Mean & SE & \\
\hline $\begin{array}{l}\text { Total cross-sectional } \\
\text { area of white muscle }\left(\mathrm{mm}^{2}\right)\end{array}$ & $9 \cdot 19^{b}$ & 0.58 & $10 \cdot 98^{\mathrm{a}}$ & 0.51 & $11 \cdot 10^{\mathrm{a}}$ & 0.55 & 0.0491 \\
\hline $\begin{array}{l}\text { Total number of white muscle fibres } \\
\text { Diameter of white muscle fibres }(\mu \mathrm{m})\end{array}$ & 15596 & 1553 & 17908 & 1051 & 15156 & 510 & $0 \cdot 186$ \\
\hline Mean & $27 \cdot 68^{\mathrm{b}}$ & 0.91 & $28.09^{b}$ & 0.67 & $30 \cdot 52^{\mathrm{a}}$ & 0.66 & 0.0470 \\
\hline Median & $24 \cdot 29^{b}$ & 0.62 & $24.85^{\mathrm{b}}$ & 0.60 & $27 \cdot 05^{\mathrm{a}}$ & 0.73 & 0.0298 \\
\hline Maximum & $70 \cdot 36$ & 2.92 & 69.91 & $2 \cdot 10$ & 77.49 & 3.54 & 0.137 \\
\hline \multicolumn{8}{|l|}{ Body characteristics } \\
\hline Weight $(g)$ & $6 \cdot 95^{\mathrm{b}}$ & 0.61 & $8.73^{\mathrm{a}}$ & 0.35 & $8 \cdot 33^{a}$ & 0.51 & 0.0336 \\
\hline Total length $(\mathrm{cm})$ & $8 \cdot 8^{b}$ & 0.3 & $9 \cdot 5^{\mathrm{a}}$ & 0.1 & $9 \cdot 5^{a}$ & 0.2 & 0.0197 \\
\hline
\end{tabular}

LF, low fat; HF, high fat.

${ }^{a, b}$ Mean values within a row with unlike superscript letters were significantly different $(P<0.05)$.

slow-MHC) after exogenous feeding, we demonstrated that the maximum hypertrophy of white muscle fibres increased during the first $90 \mathrm{df}$.

\section{Effects of early feeding with the high-fat and low-fat diets} on alevin body growth and lipid deposits

The present results showed that rainbow trout alevins responded in the same way as rainbow trout juveniles and various other fish juveniles when the dietary protein:energy ratio was changed by the addition of lipids: body growth rate was stimulated and lipid deposits were increased ${ }^{(47,48)}$. Moreover, the results reported herein showed that the better growth of alevins fed the HF diet was not fully explained by increased muscle growth. Indeed, the higher weight of $\mathrm{HF}$ diet-fed alevins at $30 \mathrm{df}$ was not associated with greater total cross-sectional areas of white and red skeletal muscles at the vent level, suggesting greater weight of the anterior part of alevins, with heavier visceral tissues and/or perivisceral adipose tissue. The subsequent comparison of alevins at
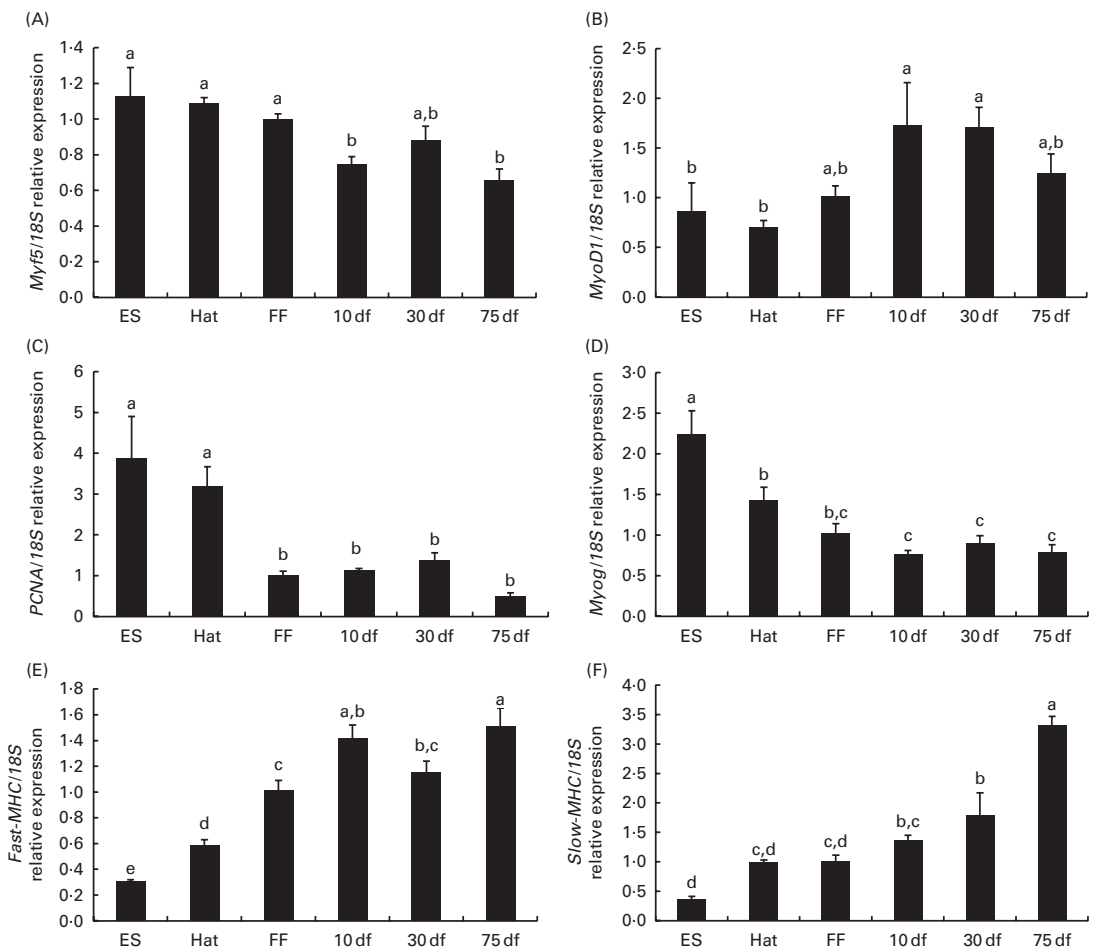

Fig. 5. Ontogenetic changes in the relative expression levels of muscle growth-related genes in rainbow trout alevins fed the low-fat diet: (A) myogenic factor 5 (Myf5); (B) myogenic differentiation 1 (MyoD1); (C) proliferating cell nuclear antigen (PCNA); (D) myogenin (Myog); (E) fast myosin heavy chain (fast-MHC) and $(\mathrm{F})$ slow-MHC. Values are means, with their standard errors represented by vertical bars. ${ }^{a, b, c, d, e}$ Mean values with unlike letters were significantly different $(P<0.05)$. ES, eyed stage; Hat, hatching; FF, first exogenous feeding; df, days of feeding. 
Table 4. Effects of early feeding with the high-fat (HF) and low-fat (LF) diets on the relative mRNA expression of muscle growth-related genes in rainbow trout alevins and juveniles

(Mean values with their standard errors)

\begin{tabular}{|c|c|c|c|c|c|c|c|c|}
\hline \multicolumn{4}{|c|}{ Genes } & \multicolumn{4}{|c|}{ Fold induction } & $P$ \\
\hline \multicolumn{9}{|c|}{ Effects of early nutrition with the HF $v$. LF diet from first feeding onwards } \\
\hline & & \multicolumn{2}{|c|}{ LF diet at $10 \mathrm{df}$} & \multicolumn{2}{|c|}{ HF diet at $10 \mathrm{df}$} & & & \\
\hline & & Mean & SE & Mean & SE & & & \\
\hline \multirow[t]{8}{*}{ Effects at $10 \mathrm{df}$} & Myf5/18S & 0.75 & 0.04 & 0.66 & 0.04 & & & 0.204 \\
\hline & MyoD1/18S & 1.73 & 0.43 & 1.34 & 0.13 & & & 0.368 \\
\hline & Myog/18S & 0.77 & 0.04 & 0.66 & 0.06 & & & 0.213 \\
\hline & PCNA/18S & $1 \cdot 15$ & 0.03 & $1 \cdot 16$ & 0.05 & & & 0.896 \\
\hline & Fast-MHC/18S & $1.42^{\mathrm{a}}$ & 0.10 & $1 \cdot 16^{\mathrm{b}}$ & 0.05 & & & 0.0383 \\
\hline & Slow-MHC/18S & 1.38 & 0.07 & $1 \cdot 28$ & 0.05 & & & 0.268 \\
\hline & & \multicolumn{2}{|c|}{ LF diet at $30 \mathrm{df}$} & \multicolumn{2}{|c|}{ HF diet at $30 \mathrm{df}$} & & & \\
\hline & & Mean & SE & Mean & SE & & & \\
\hline \multirow{8}{*}{ Effects at $30 \mathrm{df}$} & Myf5/18S & 0.88 & 0.08 & 0.83 & 0.09 & & & 0.683 \\
\hline & MyoD1/18S & 1.71 & 0.20 & 1.53 & 0.22 & & & 0.563 \\
\hline & Myog/18S & 0.90 & 0.09 & 1.23 & 0.21 & & & 0.144 \\
\hline & PCNA/18S & 1.40 & 0.16 & 1.75 & 0.15 & & & 0.156 \\
\hline & Fast-MHC/18S & $1 \cdot 15^{\mathrm{a}}$ & 0.09 & $0.67^{\mathrm{b}}$ & 0.04 & & & 0.0018 \\
\hline & Slow-MHC/18S & 1.80 & 0.37 & $1 \cdot 12$ & 0.05 & & & 0.159 \\
\hline & & \multicolumn{2}{|c|}{ LF diet at $75 \mathrm{df}$} & \multicolumn{2}{|c|}{ HF diet at $75 \mathrm{df}$} & \multicolumn{2}{|c|}{ LF diet at $90 \mathrm{df}$} & \\
\hline & & Mean & SE & Mean & SE & Mean & SE & \\
\hline \multirow[t]{6}{*}{ Effects at $75 / 90 \mathrm{df}$} & Myf5/18S & 0.66 & 0.06 & 1.00 & 0.14 & 0.93 & 0.13 & 0.343 \\
\hline & MyoD1/18S & 1.25 & 0.19 & 1.78 & 0.29 & 1.07 & 0.02 & 0.248 \\
\hline & Myog/18S & 0.79 & 0.09 & $1 \cdot 15$ & 0.13 & 0.84 & 0.06 & 0.136 \\
\hline & PCNA/18S & $0.51^{\mathrm{b}}$ & 0.07 & $0.66^{\mathrm{b}}$ & 0.08 & $1 \cdot 20^{\mathrm{a}}$ & 0.09 & 0.0014 \\
\hline & Fast-MHC/18S & 1.51 & 0.14 & 1.54 & 0.15 & 1.55 & 0.14 & 0.988 \\
\hline & Slow-MHC/18S & 3.32 & 0.15 & 3.46 & 0.22 & 3.48 & 0.18 & 0.911 \\
\hline \multicolumn{9}{|c|}{ Long-term effects of early nutrition after transfer to a common CD at $75 \mathrm{df}$} \\
\hline & & \multicolumn{2}{|c|}{$\begin{array}{l}\text { LF diet at } \\
75 \mathrm{df}+\mathrm{CD} \\
\text { for } 3 \mathrm{~m}\end{array}$} & \multicolumn{2}{|c|}{$\begin{array}{l}\text { HF diet at } \\
75 \mathrm{df}+\mathrm{CD} \\
\text { for } 3 \mathrm{~m}\end{array}$} & \multicolumn{2}{|c|}{$\begin{array}{l}\text { LF diet at } \\
75 \mathrm{df}+\mathrm{CD} \text { for } \\
3 \mathrm{~m} \text { and } 16 \mathrm{~d}\end{array}$} & \\
\hline & & Mean & SE & Mean & SE & Mean & SE & \\
\hline \multirow{6}{*}{$\begin{array}{l}\text { Effects after three further } \\
\text { months of feeding with the CD }\end{array}$} & Myf5/18S & 1.08 & $\overline{0.182}$ & $\overline{0.80}$ & $\overline{0.09}$ & 0.74 & $\overline{0.05}$ & 0.122 \\
\hline & MyoD1/18S & $1.04^{\mathrm{a}, \mathrm{b}}$ & 0.12 & $0.83^{b}$ & 0.10 & $1 \cdot 38^{\mathrm{a}}$ & 0.16 & 0.0184 \\
\hline & Myog/18S & $1.03^{\mathrm{b}}$ & 0.11 & $0.70^{\mathrm{b}}$ & 0.06 & $1.49^{\mathrm{a}}$ & 0.20 & 0.0019 \\
\hline & PCNA/18S & $1.06^{\mathrm{a}}$ & 0.15 & $0.64^{\mathrm{b}}$ & 0.07 & $0.72^{\mathrm{b}}$ & 0.05 & 0.0122 \\
\hline & Fast-MHC/18S & 1.01 & 0.07 & $1 \cdot 12$ & 0.08 & 1.05 & 0.21 & 0.845 \\
\hline & Slow-MHCl18S & 1.03 & 0.11 & 0.79 & 0.06 & 1.34 & 0.31 & 0.132 \\
\hline
\end{tabular}

df, Days of feeding after the first meal; Myf5, myogenic factor $5 ;$ MyoD1, myogenic differentiation $1 ;$ Myog, myogenin; PCNA, proliferating cell nuclear antigen; fast/slow-MHC, fast/slow-myosin heavy chain; CD, commercial diet; m, months.

${ }^{\mathrm{a}, \mathrm{b}}$ Mean values within a row with unlike superscript letters were significantly different $(P<0.05)$.

similar body weights (HF diet after $75 \mathrm{df} v$. LF diet after $90 \mathrm{df}$ ) indicated greater total cross-sectional areas of white and red skeletal muscles at the vent level in LF diet-fed alevins, which again suggests a heavier anterior part in HF diet-fed alevins. This heavier anterior part in HF diet-fed alevins was supported by a $70 \%$ higher lipid content than in LF diet-fed alevins. This is consistent with the findings obtained for larger rainbow trout showing that when the dietary protein: energy ratio is changed by the addition of lipids, there is an increase in lipid deposition around the viscera ${ }^{(2,49)}$. The present findings are original in that they add to the understanding of the early stages and demonstrate that lipid storage in alevins is, at high dietary protein levels, governed by dietary energy independently of the body weight of alevins. Indeed, the present results demonstrated that the early distribution of $\mathrm{HF}$ diets to rainbow trout alevins led to a fatty phenotype with less muscle at similar body weights than that formed with a leaner diet.

Effects of early feeding with the high-fat and low-fat diets on the expression of muscle growth-related genes and muscle growth dynamics in alevins

We demonstrated that the decrease in dietary protein:energy ratio by fat addition from first feeding onwards led to a very rapid decrease (highly significant after only $10 \mathrm{~d}$ of distribution) in the relative expression level of fast-MHC 
mRNA. This significant decrease persisted after 20 further days of HF diet feeding. In contrast, the distribution of the HF diet from first feeding onwards appeared from the present results to affect neither the relative expression levels of $M y f 5$ and MyoD1 mRNA, which are involved in the determination and activation of muscle precursor cells, nor the relative expression level of Myog mRNA, which is involved in terminal differentiation and fusion. Few other findings are available on the nutritional regulation of the expression levels of MRF and MHC during early life in fish. What is known about fast-MHC is that its mRNA expression is modulated by starvation, with an age-related relationship (increased at $1-3 \mathrm{~d}$ but decreased at $9 \mathrm{~d}$ ), in Atlantic cod larvae ${ }^{(50)}$, and decreased by a low dietary cholecalciferol level $(0.28 \mathrm{mg} / \mathrm{kg})$ and promoted by an intermediate dietary cholecalciferol level $(0.69 \mathrm{mg} / \mathrm{kg})$ in 22 and 44-d-old European sea bass larvae ${ }^{(22)}$. However, it is not modified by nucleotide enrichment of live feed in Atlantic cod larvae ${ }^{(51)}$; however, it is sensitive to dietary DHA content with an age-related relationship (higher at $26 \mathrm{~d}$ with $1 \%$ DHA, but higher at 35d with 5\% DHA) in European sea bass larvae ${ }^{(52)}$. The expression levels of $M y o D$ and Myog mRNA have been shown to be independent of diet type (Artemia nauplii $v$. commercial diet) in pacu larvae ${ }^{(53)}$, and $M y o D$ mRNA has also not shown to be modified by the nucleotide enrichment of live feed in Atlantic cod larvae ${ }^{(51)}$. In one study ${ }^{(22)}$, the importance of dietary cholecalciferol level for the expression of MRF in European sea bass larvae has been revealed, and it has been shown that according to larval age, not all MRF were similarly regulated by this nutrient. The understanding of the nutritional regulation of the early expression levels of MRF and MHC is thus only partial; however, it showed that the effects of nutrients are a function of larval age, and thus of larval stage of development, and consequently on the advancement of the myogenic process. Any nutrient that might have an impact on the early expression of MRF might have an impact on the number of myotubes formed and consequently, as fibre hypertrophy is limited by diffusion distances, govern future fish growth.

Despite the significant effects of the early decrease in dietary protein:energy ratio by fat addition on the expression of fast-MHC at 10 and $30 \mathrm{df}$, there were no significant differences in the distribution of white muscle fibre diameters of HF dietand LF diet-fed rainbow trout alevins after $30 \mathrm{df}$, indicating a delay between the changes in fast-MHC mRNA expression and myosin protein synthesis, and/or post-transcriptional regulation. The cellularity of rainbow trout white muscle thus appeared to be independent of large differences in first-feeding dietary lipid content after $30 \mathrm{df}$. This might be due to a positive post-hatching effect of the high lipid reserves of rainbow trout embryos. The protein sources ${ }^{(18,19)}$, DHA:EPA ratio $^{(20)}$, lecithin sources ${ }^{(21)}$ and cholecalciferol level ${ }^{(22)}$ utilised in first-feeding diets have been differently shown to provide a significant impact on white muscle cellularity of larvae having reduced reserves at hatching. These differences in cellular responses to the changes in dietary composition might be linked to specific nutrient effects and/or to speciesspecific differences (quantity and quality of the reserves present at hatching). Further studies are needed to clarify the early nutritional regulation of muscle growth dynamics in different species of aquaculture interest.

The hypothesis of a delay necessary to observe a phenotypic consequence of the decrease in the relative expression level of fast-MHC mRNA in alevins fed the HF diet is supported by the changes in white muscle cellularity after a longer time of feeding (75-90 df) with this diet. The comparison of the fish at a similar age ( $75 \mathrm{df})$ showed that HF diet-fed alevins had a greater total cross-sectional area of white muscle, achieved by greater maximum hypertrophy of white muscle fibres. Given that the size of HF diet- and LF diet-fed alevins was different at $75 \mathrm{df}$, their differences in white muscle cellularity at this age could be attributed both to the changes that occur normally in trout white muscle cellularity when the body length increased ${ }^{(7,8)}$ and to potential changes linked to the changes in dietary protein:energy ratio by the addition of lipids. The comparison of alevins of similar body size (HF diet-fed alevins at $75 \mathrm{df} v$. LF diet-fed alevins at $90 \mathrm{df}$ ) provided an explanation regarding which muscle growth processes the alevins fed the two diets utilised to reach a similar body size. To reach a similar body size, LF diet-fed alevins made more muscle at the vent level than HF diet-fed alevins, and they made more muscle both by a significantly higher recruitment of new white muscle fibres, as indicated by a total number of white muscle fibres being 58\% higher, and by higher hypertrophy of large fibres, as indicated by the greater number of large fibres and the maximum diameter of large fibres. Thus, there was in this experiment no relationship between high white muscle hyperplasia and rapid somatic growth. Such a relationship has been proved to exist during the early life of some other fish species fed differently, such as common carp larvae and pikeperch larvae fed compound diets that contained different protein sources $^{(18,19)}$, Atlantic cod larvae fed enriched rotifers that differed in their DHA:EPA ratio ${ }^{(20)}$ and gilthead sea bream larvae fed compound diets that contained different lecithin sources ${ }^{(21)}$. The fact that there was no relationship between high white muscle hyperplasia and rapid growth when trout alevins were fed high lipid levels is probably due to the fact that the greater increase in the body weight of HF diet-fed alevins was not fully explained by their increase in the total cross-sectional area of white muscle at the vent level. The present results, with fewer white muscle fibres and lower maximum hypertrophy of white muscle fibres in HF diet-fed alevins when compared with LF diet-fed alevins at similar body weights ( $75 \mathrm{df}$ for the former $v .90 \mathrm{df}$ for the latter), suggest preferential deposition of supplementary energy in tissues other than caudal skeletal muscle. A recent study in weaning rats has led to similar conclusions: a maternal postnatal HF diet (i.e. a HF diet provided from birth onwards) promoted an obese phenotype, characterised by high body fat, fat accumulation in the retroperitoneal area, and altered skeletal muscle morphology with reduced myofibre density ${ }^{(54)}$. We did not find a link between the relative expression level of fast-MHC mRNA, white muscle cellularity and body growth in rainbow trout alevins fed the HF and LF diets. The higher expression level of fast-MHC mRNA in LF diet-fed alevins at $30 \mathrm{df}$ did not correlate with greater muscle growth, a different muscle growth process or greater body growth. Similarly, there was no link observed between 
fast-MHC mRNA expression, muscle cellularity and body growth in juvenile rainbow trout fed different protein sources with different amino acid profiles ${ }^{(28,29)}$ and no correlation observed between fast-MHC mRNA expression and body growth in the juveniles of Senegalese sole fed different dietary lipid levels ${ }^{(55)}$. In contrast, a link between fast-MHC mRNA expression, muscle cellularity and body growth has been demonstrated in European sea bass larvae fed different levels of cholecalciferol ${ }^{(22)}$. These examples suggest that the correlation between fast-MHC mRNA expression, muscle cellularity and body growth might be species-specific, stage-specific and nutrient-specific. Early postnatal (mammals) and posthatching (birds, reptiles, amphibians and fish) stages are, for all vertebrates, stages during which cell multiplication and differentiation continue to occur with, in addition to organ specificity, group specificity and species specificity within each group. The early stages of fish that hatch with yolk reserves and an unopened mouth appeared from the present study to be very sensitive to an early decrease in dietary protein:energy ratio by the addition of lipids, which was shown here to modify the balance between myogenesis and adipogenesis in trout alevins. These findings, which are innovative for fish, expand the growing understanding of the negative effects of early-life obesity. The present results in trout are consistent with those obtained when young mice are fed a HF diet (heavier animals with reduced muscle mass ${ }^{(56)}$ ).

\section{Long-term effects of initial feeding with \\ a high-fat or a low-fat diet}

Interestingly, we also demonstrated that an early decrease in dietary protein:energy ratio by the addition of lipids had a long-term effect on the body growth of juvenile rainbow trout that were fed the HF diet during the first $75 \mathrm{df}$ maintaining their higher body weights after three additional months of feeding with a commercial diet. Our findings confirmed that first feeding dietary composition had an impact on juvenile growth, as already demonstrated by Koedijk et al. ${ }^{(57)}$ with Atlantic cod larvae fed various live prey, and extended understanding by highlighting the importance of a change in a specific nutritional component for first-feeding rainbow trout. There was a persistent effect of initial feeding with the HF diet on the muscle growth of rainbow trout juveniles, as indicated by a greater total cross-sectional area of white muscle after $3 \mathrm{mf}$ with the commercial diet in initially HF dietfed juveniles than in initially LF diet-fed juveniles. The higher body weight and the greater total cross-sectional area of white muscle of initially HF diet-fed juveniles did not correlate with the greater expression level of fast-MHC mRNA. Initial feeding of Atlantic cod larvae with different live prey also had no effect on the expression levels of MHC in juveniles fed a commercial diet to satiety for 3 months ${ }^{(58)}$. However, we provided evidence that an early decrease in dietary protein:energy ratio by the addition of lipids induced long-term differences in the expression levels of genes involved in the early steps of myogenesis with, when compared at similar body weight after the commercial feeding period, higher relative expression levels of MyoD1 and Myog mRNA in initially LF diet-fed juveniles (i.e. in fish that promoted muscle growth when compared at similar body weights at the end of the experimental feeding period). This is consistent with the findings showing that overfeeding mice during the postnatal life with a HF diet reduces myogenic stem cell function ${ }^{(56)}$. Taking into account that there was a delay between changes at the mRNA and cellular levels in alevins, a longer commercial feeding period might be similarly necessary in juveniles to observe the cellular consequences of higher expression levels of MyoD1 and Myog mRNA in initially LF diet-fed juveniles. Another proof of a persisting effect of initial feeding on muscle growth came from a comparison of juveniles at similar body weights (initially HF diet-fed juveniles after $3 \mathrm{mf}$ with the commercial feed $v$. initially LF diet-fed juveniles after $6 \mathrm{mf}+16 \mathrm{df}$ with the commercial feed). This comparison showed that initially HF diet- and LF diet-fed juveniles did not achieve the same total cross-sectional area of white muscle by the same process: initially LF diet-fed juveniles retained the ability to maximise fibre enlargement that they had after $90 \mathrm{df}$ for at least three further months. To our knowledge, this constitutes the first evidence of a long-lasting effect of early nutrition on the expression of MyoD1 and Myog mRNA and on the cellularity of white axial skeletal muscle in a fish species. This finding demonstrates that the activity of muscle precursor cells present in the white muscle of trout juveniles (i.e. satellite cells) might be programmed by early nutrition.

\section{Acknowledgements}

The authors thank P. Aguirre and P. Peyrotte for preparation and analysis of the HF and LF diets, as well as J. P. Fourriot and F. Vallee for their assistance with fish rearing and sampling.

The authors' contributions are as follows: H. A.-D. conceived the reserach on muscle development and growth. H. A.-D. and F. M. designed the grading, sampling and feeding protocols. M. C., C. D. and V. G.-D. performed the molecular, histological and chemical-histochemical analyses of alevins; P. M. was responsible for fish farm work; H. A.-D. analysed the data on body growth and the data on muscle development and growth. F. M. analysed the quantitative data on lipid deposits; H. A.-D. interpreted the results and wrote the paper.

There are no conflicts of interest.

\section{References}

1. Lee DJ \& Putnam GB (1973) The response of rainbow trout to varying protein/energy ratios in a test diet. $J$ Nutr $\mathbf{1 0 3}$, 916-922

2. Takeuchi T, Watanabe T \& Ogino C (1978) Optimum ratio of protein to lipid in diets of rainbow trout. Bull Jap Soc Sci Fish 44, 683-688.

3. Kaushik SJ \& Medale F (1994) Energy requirements, utilization and dietary supply to salmonids. Aquaculture 124, 81-97.

4. Mazurais D, Darias M, Zambonino-Infante JL, et al. (2011) Transcriptomics for understanding marine fish larval development. Can J Zool 89, 599-611.

5. Alami-Durante H \& Bacou F (2000) Metabolic differentiation of myotomal muscles in a teleost fish, the sea bass (Dicentrarchus labrax L.). Comp Biochem Physiol A 126, S5. 
6. Alami-Durante H (1990) Growth of organs and tissues in carp (Cyprinus carpio L.) larvae. Growth Dev Aging 54, $109-116$

7. Weatherley AH, Gill HS \& Rogers SC (1980) The relationship between the mosaic muscle fibres and size in rainbow trout (Salmo gairdneri). J Fish Biol 17, 603-610.

8. Stickland NC (1983) Growth and development of muscle fibres in the rainbow trout (Salmo gairdneri). J Anat 137, 323-333.

9. Rowlerson A \& Veggetti A (2001) Cellular mechanisms of post-embryonic muscle growth in aquaculture species. In Muscle Development and Growth, Fish Physiology Series, vol. 18, pp. 103-140 [IA Johnston, editor]. San Diego, CA: Academic Press.

10. Stickland NC, White RN, Mescall PE, et al. (1988) The effect of temperature on myogenesis in embryonic development of the Atlantic salmon (Salmo salar L.). Anat Embryol (Berl) 178, 253-257.

11. Alami-Durante H, Rouel M \& Kentouri M (2006) New insights into temperature-induced white muscle growth plasticity during Dicentrarchus labrax early life: a developmental and allometric study. Mar Biol 149, 1551-1565.

12. Alami-Durante H, Olive N \& Rouel M (2007) Early thermal history significantly affects the seasonal hyperplastic process occurring in the myotomal white muscle of Dicentrarchus labrax juveniles. Cell Tissue Res 327, 553-570.

13. Macqueen DJ, Robb DHF, Olsen T, et al. (2008) Temperature until the 'eyed stage' of embryogenesis programmes the growth trajectory and muscle phenotype of adult Atlantic salmon. Biol Lett 4, 294-298.

14. Salze G, Alami-Durante H, Barbut S, et al. (2014) Nutrient deposition partitioning and priorities between body compartments in two size classes of rainbow trout in response to feed restriction. Br J Nutr 111, 1361-1372.

15. Weatherley AH, Gill HS \& Rogers SC (1979) Growth dynamics of muscle fibres, dry weight, and condition in relation to somatic growth rate in yearling rainbow trout (Salmo gairdneri). Can J Zool 57, 2385-2392.

16. Beardall CH \& Johnston IA (1985) The ultrastructure of myotomal muscles of the saithe Pollachius virens L. following starvation and refeeding. Eur J Cell Biol 39, 105-111.

17. Kiessling A, Storebakken T, Asgard T, et al. (1991) Changes in the structure and function of the epaxial muscle of rainbow trout (Oncorbynchus mykiss) in relation to ration and age - I. Growth dynamics. Aquaculture 93, 335-356.

18. Alami-Durante H, Fauconneau B, Rouel M, et al. (1997) Growth and multiplication of white skeletal muscle fibres in carp larvae in relation to somatic growth rate. J Fish Biol 50, 1285-1302.

19. Ostaszewska T, Dabrowski K, Wegner A, et al. (2008) The effects of feeding on muscle growth dynamics and the proliferation of myogenic progenitor cells during pike perch development (Sander lucioperca). J World Aquac Soc 39, 184-195.

20. Galloway TF, Kjorsvik E \& Kryvi H (1999) Muscle growth and development in Atlantic cod larvae (Gadus morbua L.) related to different somatic growth rates. J Exp Biol 202, 2111-2120.

21. Alves Martins D, Estevez A, Stickland NC, et al. (2010) Dietary lecithin source affects growth potential and gene expression in Sparus aurata larvae. Lipids 45, 1011-1023.

22. Alami-Durante H, Cluzeaud M, Bazin D, et al. (2011) Dietary cholecalciferol regulates the recruitment and growth of skeletal muscle fibers and the expression of myogenic regulatory factors and the myosin heavy chain in European sea bass larvae. J Nutr 141, 1-6.
23. Kamaszewski M, Prasek M, Ostaszewska T, et al. (2014) The influence of feeding diets containing wheat gluten supplemented with dipeptides or free amino acids on structure and development of the skeletal muscle of carp (Cyprinus carpio). Aquacult Int 22, 259-271.

24. Fauconneau B, Andre S, Chmaitilly J, et al. (1997) Control of skeletal muscle fibres and adipose cell size in the flesh of rainbow trout. J Fish Biol 50, 296-314.

25. Johnston IA, Manthri S, Alderson R, et al. (2002) Effects of dietary protein level on muscle cellularity and flesh quality in Atlantic salmon with particular reference to gaping. Aquaculture 210, 259-283.

26. Bjornevik M, Beattie C, Hansen T, et al. (2003) Muscle growth in juvenile Atlantic salmon as influenced by temperature in the egg and yolk sac stages and diet protein level. J Fish Biol 62, 1159-1175.

27. Silva P, Valente LMP, Galante MH, et al. (2009) Dietary protein content influences both growth and size distribution of anterior and posterior muscle fibres in juveniles of Pagellus bogaraveo (Brunnich). J Musc Res Cell Motil 30, 29-39.

28. Alami-Durante H, Medale F, Cluzeaud M, et al. (2010) Skeletal muscle growth dynamics and expression of related genes in white and red muscle of rainbow trout fed diets with graded levels of a mixture of plant protein sources as substitutes for fish meal. Aquaculture 303, 50-58.

29. Alami-Durante H, Wrutniack-Cabello C, Kaushik SJ, et al. (2010) Skeletal muscle cellularity and expression of myogenic regulatory factors and myosin heavy chains in rainbow trout (Oncorbynchus mykiss): effects of changes in dietary plant protein sources and amino acid profiles. Comp Biochem Physiol A 156, 561-568.

30. Escaffre AM \& Bergot P (1984) Utilization of the yolk in rainbow trout alevins (Salmo gairdneri Richardson): effect of egg size. Reprod Nutr Develop 24, 449-460.

31. Escaffre AM \& Bergot P (1985) Effet d'une alimentation précoce ou retardée sur la croissance d'alevins de truite arc-en-ciel (Salmo gairdneri) issus d'œufs de tailles différentes (Influence of early or delayed feeding on growth of rainbow trout alevins (Salmo gairdneri) originating from eggs of different sizes). Bull Fr Pêche Piscic 296, 17-28.

32. Thivend P, Mercier C \& Guilbot A (1972) Determination of starch with glucoamylase. In Methods in Carbobydrate Chemistry, vol. 6, pp. 100-105 [RL Whilster and JN Bemillier, editors]. New York, NY: Academic Press.

33. Folch J, Lees M \& Sloane Stanley GH (1956) A simple method for the isolation and purification of total lipides from animal tissues. J Biol Chem 226, 497-509.

34. Gabe M (1968) Techniques Histologiques. Paris: Masson. 1113 pp.

35. Chauvigné F, Gabillard JC, Weil C, et al. (2003) Effect of refeeding on IGFI, IGFII, IGF receptors, FGF2, FGF6, and myostatin mRNA expression in rainbow trout myotomal muscle. Gen Comp Endocrinol 132, 209-215.

36. Kamangar BB, Gabillard JC \& Bobe J (2006) Insulin-like growth factor-binding protein (IGFBP)-1, -2, -3, -4, -5, and -6 and IGFBP-related protein 1 during rainbow trout postvitellogenesis and oocyte maturation: molecular characterization, expression profiles, and hormonal regulation. Endocrinology 147, 2399-2410.

37. Pfaffl MW (2001) A new mathematical model for relative quantification in real-time RT-PCR. Nucleic Acid Res 29, e45.

38. Weatherley AH, Gill HS \& Lobo AF (1988) Recruitment and maximal diameter of axial muscle fibres in teleost and their relationship to somatic growth and ultimate size. $J$ Fish Biol 33, 851-859. 
39. Sabourin LA \& Rudnicki MA (2000) The molecular regulation of myogenesis. Clin Genet 57, 16-25.

40. Bravo R, Frank R, Blundell PA, et al. (1987) Cyclin/PCNA is the auxiliary protein of DNA polymerase- $\delta$. Nature $\mathbf{3 2 6}$, 515-517.

41. Wilkes D, Xie SQ, Stickland N, et al. (2001) Temperature and myogenic factor transcript levels during early development determine muscle growth potential in rainbow trout (Oncorbynchus mykiss) and sea bass (Dicentrarchus labrax L.). J Exp Biol 204, 2763-2771.

42. Mennigen JA, Skiba-Cassy S \& Panserat S (2013) Ontogenetic expression of metabolic genes and microRNAs in rainbow trout alevins during the transition from the endogenous to the exogenous feeding period. J Exp Biol 216, 1597-1608.

43. Stoiber W, Haslett JR, Wenk R, et al. (2002) Cellularity changes in developing red and white fish muscle at different temperatures: simulating natural environmental conditions for a temperate freshwater cyprinid. J Exp Biol 205, $2349-2364$

44. Mozdziak PE, Evans JJ \& McCoy DW (2002) Early posthatch starvation induces myonuclear apoptosis in chickens. $J$ Nutr 132, 901-903.

45. Halevy O, Nadel Y, Barak M, et al. (2003) Early posthatch feeding stimulates satellite cell proliferation and skeletal muscle growth in turkey poults. J Nutr 133, 1376-1382.

46. Johansen KA \& Overturf K (2005) Quantitative expression analysis of genes affecting muscle growth during development of rainbow trout (Oncorbynchus mykiss). Mar Biotechnol 7, 576-587.

47. Shearer KD (1994) Factors affecting the proximate composition of cultured fishes with emphasis on salmonids. Aquaculture 119, 63-88.

48. NRC (2011) Nutrient Requirements of Fish and Shrimp. Washington, DC: National Academies Press. 376 pp.

49. Diaz J, Corraze G, Arzel J, et al. (1999) Effets du rapport protéine/énergie des régimes alimentaires chez la truite et le bar en élevage. Perspectives de contrôle nutritionnel des dépôts lipidiques (Nutritional control of lipid deposition in rainbow trout and European sea bass: effect of dietary protein/energy ratio). Cybium 23, 127-137.

50. MacNamara PT, Caldarone EM \& Buckley LJ (1999) RNA/ DNA ratio and expression of $18 \mathrm{~S}$ ribosomal RNA, actin and myosin heavy chain messenger RNAs in starved and fed larval Atlantic cod (Gadus morhua). Mar Biol 135, 123-132.

51. Lanes CFC, Bolla S, Fernandes JMO, et al. (2012) Nucleotide enrichment of live feed: a promising protocol for rearing of Atlantic cod Gadus morhua larvae. Mar Biotechnol 14, 544-558.

52. Betancor MB, Izquierdo M, Terova G, et al. (2013) Physiological pathways involved in nutritional muscle dystrophy and healing in European sea bass (Dicentrarchus labrax) larvae. Comp Biochem Physiol A 164, 399-409.

53. Leitao N, Dal Pai-Silva M, Losi Alves de Almeida F, et al. (2011) The influence of initial feeding on muscle development and growth in pacu Piaractus mesopotamicus larvae. Aquaculture 315, 78-85.

54. Pantaleao LC, Teodoro GFR, Torres-Leal FL, et al. (2013) Maternal postnatal high-fat diet, rather than gestational diet, affects morphology and mTOR pathway in skeletal muscle of weaning rats. J Nutr Biochem 24, 1340-1348.

55. Campos C, Valente LPM, Borges P, et al. (2010) Dietary lipid levels have a remarkable impact on the expression of growth-related genes in Senegalese sole (Solea senegalensis Kaup). J Exp Biol 213, 200-209.

56. Woo M, Isganaitis E, Cerletti M, et al. (2011) Early life nutrition modulates stem cell number: implications for muscle mass and repair. Stem Cells Dev 20, 1763-1769.

57. Koedijk RM, Folkvord A, Foss A, et al. (2010) The influence of first-feeding diet on the Atlantic cod Gadus morbua phenotype: survival, development and long-term consequences for growth. J Fish Biol 77, 1-19.

58. Koedijk RM, Le François N, Blier PU, et al. (2010) Ontogenetic effects of diet during early development on growth performance, myosin mRNA expression and metabolic enzyme activity in Atlantic cod juveniles reared at different salinities. Comp Biochem Physiol A 156, 102-109. 